\title{
Street Names through Sociological Lenses. Part II: Constructionism and Utilitarianism
}

\author{
Mihai Stelian Rusu ${ }^{1 *}$
}

${ }^{1}$ Lucian Blaga University of Sibiu, Department of Social Work, Journalism, Public Relations, and Sociology, 2A Lucian Blaga, 550169 Sibiu, Romania.

KEYWORDS

Sociology of street

names

Politics of space

Linguistic landscapes

Critical toponymies

Human geography

Social theory
A BSTRACT

As toponymic means of inscribing urban space, street names have been addressed mainly by human geographers, who have articulated the field of critical place-name studies. In this paper, I continue the endeavor started in the previous issue published in Social Change Review of reading street names through sociological lenses. Whereas in the first part of this twopart contribution the analysis was made from functionalist and conflictualist perspectives, this second and final part employs social constructionism and the utilitarian theoretical tradition in making sociological sense of street nomenclatures. First, conceiving of street names as forming discursively constructed linguistic landscapes, the paper shows how urban namescapes the "city-text" - are written, erased, and rewritten to reflect the shifting political powers. Second, the paper examines the neoliberal processes of place branding and toponymic commodification by which street names are turned into sought-after urban commodities with transactional value on the real estate market. The paper concludes by inviting sociologists to join the conversation on street names, which should become an important topic of sociological reflection.

\footnotetext{
* Contact address: mihai.rusu@ulbsibiu.ro (M. S. Rusu)
} 


\section{Introduction: Reading street names sociologically}

Street names constitute efficient toponymic means of spatial organization as well as powerful devices for inscribing the landscape with symbols, values, and meanings. As critical scholars of toponymy have pointed out, when used in commemorative purposes, street names become "sites of memory that conflate power, remembrance, language and space" (Azaryahu 2012: 388). Irrespective of their pragmatic or symbolic function - acting as a spatial technology of governmentality employed by administrative authorities to manage efficiently the territory or as politicized toponymic means of producing a symbolic geography of public memory in the built environment - street names have not featured on sociologists' agenda.

While a sociology of street names is nowhere to be found in the academic landscape of social sciences, most contributions to developing an understanding of urban nomenclatures and the politics of (re)naming were made from within various inflections of human geography. These political, cultural, and social geographers have articulated the interdisciplinary field of critical toponymic studies and started conceiving of place naming practices through different strands of social theory (Berg and Vuolteenaho 2009; RoseRedwood, Alderman, and Azaryahu 2018). In this regard, cultural geographers have resorted to a repertoire of metaphors in making sense of memorial landscapes. Urban nomenclatures could thus be conceived of via the metaphors of "text" (street names as discourse spelled out in space), "arena" (street names as sites of cultural, political, and memorial strife as well as realms of struggle for ethnic recognition and racial justice), and "performance" (street names as socio-spatial practices enacted by inscribing identities in place) (Dwyer and Alderman 2008). Others have charted three main concurrent but complementary approaches developed in the aftermath of the "critical turn" in place-name studies: political semiotics (street names as ideological signs inscribed into the landscape), governmentality studies (street names as technologies of spatial organization), and normative theories of social justice and symbolic resistance (street names as cultural and 
memorial arenas where power struggles are being fought) (Rose-Redwood, Alderman, and Azaryahu 2010).

In this paper, which is split into two installments, I advance a re-reading of street names through the paradigmatic lenses provided by sociological theory. Drawing on Randall Collins' (1994) quadratic classification of sociological theory, in this contribution I set out to reinterpret the scholarship done on street names in the light of the sociological traditions of thought corresponding to functionalism, conflictualism, interactionism, and utilitarianism. In the first installment of this two-part series, I approached street names from a functionalism perspective and examined the power struggles and contentious politics underpinning toponymic inscription by resorting to an analytical framework informed by conflict theory (Rusu 2020a). In this final part, I complete the analysis of street names from sociology's four theoretical traditions. I begin by embracing social constructionism and conceive of street names as a discursively constructed "city-text" through the writing, erasing, and re-writing of meanings onto urban streetscape. Then, from a utilitarian perspective, I look at the commodification of street names and the role played by toponymy within neoliberal urban governance.

\section{Constructionism: Urban nomenclature as city-text}

What Randall Collins (1994) calls the "micro-interactionist tradition" in sociological theory was inaugurated by George Herbert Mead's (1934) seminal thoughts on the ontogenesis of the social self which he viewed as articulating progressively during intense social interaction with "significant others." Mead's ideas were further developed and systematized by his disciple, Herbert Blumer, in the paradigm of symbolic interactionism (Blumer 1969). The central postulate underpinning symbolic interactionism consists in conceiving society as an intersubjective world of shared meanings that emerges out of the everyday interactions between ordinary individuals. Another related strand of sociological thought comes from Alfred Schütz's 
(1967) [1932] phenomenological explorations of the taken-for-granted structures of meaning and tacit knowledge which underly everyday social life (Polanyi 1958). After the publication of Peter L. Berger and Thomas Luckmann's (1966) influential book, the idea that the social world is "socially constructed" and that the phenomena that constitute it are themselves "social constructs," rather than given from nature (datum) or biologically determined, has achieved canonical status within sociological thought and beyond (Burr 1995).

From social constructionist premises, street nomenclatures can be conceived of as systems of signifying the territory to which political authorities' resort for constructing the space as a meaningful "linguistic landscape." According to Rodrigue Landry and Richard Y. Bourhis (1997), who have coined the term, "the language of public road signs, advertising billboards, street names, place names, commercial shop signs, and public signs on government building combines to form the linguistic landscape of a given territory, region, or urban agglomeration" (p. 25). Political authorities produce such meaningful linguistic landscapes through using street names, among other toponymic means of spatial inscription, to configure an urban geography of public memory and collective identity that anchors in space the broader structures of meaning shared within a particular community. In the study of these toponymic systems of signifying the landscape, the perspective provided by political semiotics has been intersected with the Foucauldian discourse analysis and put to work in understanding street names as "texts" written on the urban fabric which inscribe into the landscape the political values, historical memories, and the heroic protagonists of the current social order (that is, a society's cultural structures of meaning). Street names thus constitute discursive formations that materialize in space the ideological ethos of the political regime and, ipso facto, buttresses and legitimates its domination.

Much of the extant literature turned to the concept of "city-text" as a theoretical framework grounded in semiotics that would enable researchers to read urban linguistic landscapes. A major source of inspiration came from 
Roland Barthes' project of developing an "urban semiology." In his semiotic reflections, Barthes (1997) [1967] writes that "the city is a discourse and this discourse is truly a language: the city speaks to its inhabitants" (p. 160). He goes on to insists that "the problem is to bring an expression like 'the language of the city' out of the purely metaphorical stage." Street names provide such an escape from the bounds of figurative speech. As we shall see, researchers have argued convincingly that urban namescapes and street nomenclatures are toponymic discourses that spell out in space the historical myths, cultural imaginary, and political ethos of a social order.

Among the first to engage in a critical reading of city streets, Priscilla F. Ferguson (1988) explored the cultural genesis and political production of street names which she conceived as both toponymic means of conferring meaning on urban space and spatial practices of power enacted by political authorities in their bid to control the city. In her seminal study, Ferguson (1988) argued that "street names form a signal element of the larger text that every city spreads before us" (p. 395). Although cautioning against the trap of textual reductionism - "it is obvious that we cannot 'read' a city solely through its streets" - her paper on Paris's streetscape revealed how politics and culture can be read through the semiotic code of street names. The semiotic approach first applied to reading the street names was subsequently extrapolated from urban namescapes to the landscape writ large. In a work bearing a programmatic title - The City as Text - cultural geographer James $S$. Duncan (1990) advanced a "hermeneutic perspective of landscape interpretation" which renders the landscape as "a signifying system of great but unappreciated social and political importance" and reads it accordingly not in terms of morphological features but as a "pervasive cultural production" (p. 3).

Such a semiotic framework opened up new perspectives from which to examine the political construction of the urban space (theorized as the political writing of the city-text) in the historical context of state formation and nation-building (Cohen and Kliot 1992). Another strand of research, led by the works of Maoz Azaryahu on (East) Berlin, grasped the re-writing of the 
city-text in the aftermath of significant power shifts. In a series of papers, Azaryahu articulated a theoretical framework around the concept of "citytext" while simultaneously setting up a methodology for documenting street name changes following regime changes. In an influential study that had set in motion a research program on street name changes, Azaryahu (1990) explored the patterns of "denazification of city texts" in Berlin, Vienna, Hamburg, and Leipzig. The semiotic model of reading urban nomenclature as city-text was elaborated theoretically in Azaryahu's paper on the power of commemorative street names. In this engaging piece, Azaryahu (1996) characterizes the city-text as an urban discourse made up of historical narratives that canonize into the landscape a particular geography of public memory. In contrast to other cultural and material inscriptions such as history textbooks and monuments which are read in educational and ceremonial contexts, "the reading of a city-text is embedded into everyday activities" (Azaryahu 1996: 324). This mundane feature of street names renders them into powerful semiotic devices of insidiously introducing ideological content into the structures of daily life. As a consequence, hegemonic ideologies become taken for granted while the structures of power are reified as objective and necessary institutional realities (Berger and Luckmann 1966: 106).

Following Azaryahu's works, the city-text model has been employed extensively by toponymy scholars in unpacking the semiotic discourse encoded into the urban landscapes of multiple cities, especially from Central and Eastern Europe (CEE), a region that has been a "hotspot" of research in critical toponymies (Giraut and Houssay-Holzschuch 2016). In Budapest, Emilia Palonen $(2008 ; 2015)$ has examined the politics of commemoration in the context of post-socialist change and shown how the city-text has been a "locus of dispute" between multiple political actors situated at different levels of authority - the nation-state, the metropolitan municipality, and the district -, each of them pursuing divergent administrative and commemorative agendas. What her research has pointed out was that the post-communist city text in Budapest emerged as a "negotiated order" which was the outcome of the protracted interactions between various levels of political authority 
(Strauss 1978). Other researchers have extended the paradigm by covering the city-texts of Zagreb (Šakaja and Stanić 2018), Košice (Chloupek 2019), and Timișoara (Crețan and Matthews 2015).

In the latter location, which was the birthplace of Romania's anticommunist revolution of 1989 (Siani-Davies 2007), the authors have documented the reshaping of Timișoara's urban nomenclature as a "martyr city-text" by inscribing into the landscape the memory of 53 victims of the revolution. Extending the political semiotic model so as to cover not only the official culture materially textualized in the urban space by political authorities, Remus Crețan and Philip W. Matthews (2015) have probed into how ordinary citizens react to and make sense of street name changes. They found an essential tension subsisting between the municipality's attempt of institutionalizing the memory of the revolution and locals' disapproval of street renamings. The city dwellers' preference for a stable namescape calls for a "politics of practicality" that would inflict minimal changes to the existing city-text.

As city-texts, street nomenclatures are amenable to a Foucauldian analysis as "discursive formations," since they constitute a heterogenous body of statements dispersed onto space that are, however, structured by a set of rules of formations that govern their "coexistence, maintenance, modification, and disappearance" (Foucault 1972: 38). Michel Foucault's theoretical legacy hovers over the study of place names in yet another way. I have shown in the first installment of this two-part paper how his seminal ideas on governmentality have informed a rich strand in critical toponymies which explored street names as toponymic practices of ordering urban space and thus enabling its efficient administration, policing and fiscalization (Rusu 2020a). Another inspiration came from Foucault's thoughts on "dispositif." In an interview from 1977 conducted by a round-table of historians, Foucault defined the term apparatus (dispositif) as "a thoroughly heterogeneous ensemble consisting of discourses, institutions, architectural forms, regulatory decisions, laws, administrative measures, scientific statements, philosophical, moral and philanthropic propositions" (Foucault 1980: 194). 
Drawing on this raw insight, Frédéric Giraut and Myriam HoussayHolzschuch (2015) have undertaken the ambitious task of articulating an integrated theoretical framework for the study of toponymies by considering place naming as dispositif. Foucault's concept is especially suited, given that place naming involves discursive practices (the names themselves), technologies of power (renaming the streetscape), as well as material artifacts (street nameplates and road signage, but also maps, city guides, and address directories).

Giraut and Houssay-Holzschuch (2015) conceive of the process of place naming as occurring in an apparatus consisting of three elements: a) the geopolitical context in which place naming is performed, which ranges from conquests and revolutions to emergence and commodification; $b$ ) the nominal technologies of power, which themselves vary in terms of the aims to which they are oriented, from cleansing and founding to restoring and promoting; and finally, c) the actors who do the naming and/or have a stake in the process, which are the state power, civil society, and the private sector (pp. 7-11). This overall theoretical framework enables a wide number of possible combinations between the different components making up the model. However, not all of these abstract possibilities have empirical grounding. Based on a literature review, the authors have pointed out some nexuses, that is to say, those elective affinities between geopolitical contexts and the nominal technologies of power. 
Table 1. Nexuses in place naming processes for geopolitical contexts, technologies, and actors

\begin{tabular}{|c|c|c|c|c|}
\hline \multirow{2}{*}{$\begin{array}{l}\text { Technologies } \\
\text { of power }\end{array}$} & \multicolumn{4}{|c|}{ Geopolitical context } \\
\hline & Conquest & Revolution & Emergence & Commodification \\
\hline Cleansing & $\begin{array}{l}++ \\
\text { (central } \\
\text { state) }\end{array}$ & $\begin{array}{l}+++ \\
\text { (central state) }\end{array}$ & - & - \\
\hline Founding & $\begin{array}{l}+++ \\
\text { (central } \\
\text { state) }\end{array}$ & $\begin{array}{l}+++ \\
\text { (central state) }\end{array}$ & $\begin{array}{l}++ \\
\text { (local state \& } \\
\text { private sector) }\end{array}$ & - \\
\hline Restoring & - & $\begin{array}{l}++ \\
\text { (central state) }\end{array}$ & - & - \\
\hline Promoting & - & - & $\begin{array}{l}++ \\
\text { (local state \& } \\
\text { private sector) }\end{array}$ & $\begin{array}{l}+++ \\
\text { (local state \& } \\
\text { private sector) }\end{array}$ \\
\hline
\end{tabular}

Note: The plus signs (+) denote the empirical probability of the arrangement, while the em dash (-) suggests that the combination is improbable to be found in empirical reality. In parentheses, the table indicates the main actor involved in the place naming process.

Source: adapted from Giraut and Houssay-Holzschuch (2015: 14)

The areas highlighted in different shades of grey delineate two preferential nexuses between the three components of place naming dispositifs, that is, geopolitical context, technologies of power, and actors. A first nexus, shaded in dark grey, suggests a preferential combination of conquest and revolution (contexts), cleansing and founding (technologies), and the central state power (actors). A large corpus of scholarship in critical toponymies has pointed out the extensive renaming done by state authorities in the contexts of colonialism (Cohen and Kliot 1992; Bigon 2009), imperialism (Rose-Redwood, Alderman, and Azaryahu 2010), and nation-building (Yeoh 1992; 1996; Rusu 2019a; 2019b). Especially following revolutions and conquests, new regimes and rulers appropriate the space over which they exert political sovereignty through the dual toponymic means of naming and renaming the landscape. This implies cleansing the toponymic legacy of the 
former social order followed by founding a new political formation through re-inscribing the territory with the symbols and heroes of the new rulers.

Colored in light grey is a second nexus that combines the geopolitical contexts of emergence and commodification with the technologies of founding and promoting usually enacted by local state authorities in partnership with the private sector. This particular nexus, which is characterized by the commodification of toponymy and the branding of place for commercial purposes, will be discussed at length in the following section, where I look at street names through utilitarian lenses. What the authors of this theoretical framework leave under-discussed is the combination of revolution and toponymic restoration. A solid body of scholarship has compellingly shown that post-socialist regimes from Central and Eastern Europe have resorted to a politics of back-naming by which they have sought to restore the names existing before the state-socialist orders. In Moscow, this restorative project was initiated before the formal dissolution of the Soviet Union, when in late 1990 the city's commission responsible for urban nomenclature announced that "six squares, twenty streets, and ten Metro stations were to have the original, pre-Soviet, names restored" and others are soon to follow suit (Gill 2005: 483). In post-socialist Bucharest, the municipality issued a guideline for renaming streets which "explicitly stated that streets should return to their 'traditional' (pre-World War Two) names." Consequently, 67 of the 172 streets (39.2\%) renamed until 1997 that existed before the socialist period were given back their old, interwar names (Light 2004: 162). A slightly larger percentage was found in post-socialist Romania's educational namescape, where an analysis of name changes in high schools from across the country reported that 40 out of the 89 schools (44.9\%) that were renamed received their pre-communist name (Rusu 2019b: 95).

Examined from a constructionist perspective as a city-text that is written and re-written in the course of history depending on the shifting structures of power, street names reveal their intrinsic fragility. Recent studies have resorted to multivariate statistical analyses to figure out the factors patterning toponymic transformation following a regime change. A comparative 
analysis of three major secondary cities from Transylvania, Romania (Brașov, Cluj-Napoca, and Sibiu) has employed multilinear logistic regression on a comprehensive set of spatial data in order to model statistically post-socialist toponymic change (Rusu 2020b). The results have shown that most vulnerable to renaming are those streets bearing politicized names, directly related to the former communist regime. In addition to this rather intuitive finding, the study also identified topographic factors underlying street name changes: it found a positive statistical relationship between an artery's probability of renaming and its location (measured in the physical distance from the city's central market square). Secondly, a street's vulnerability in the face of toponymic revision is also associated with the artery's size: the larger the thoroughfare, the bigger the chances of becoming a target for renaming. A social constructionist approach as the one embraced in the studies described above enables researchers to flash out the politically constructed nature of urban nomenclatures. Besides emphasizing the historical process of producing place and space, a social constructionist approach to street nomenclatures is most epistemically powerful when employed to deconstruct the structure of meanings that underwrites urban namescapes.

\section{Utilitarianism: Street names as toponymic commodity}

The utilitarian tradition has its intellectual moorings in the social contract theory developed by British philosophers starting with the 17th century, as exposed for instance in Thomas Hobbes' (2008) [1651] treatise on Leviathan. From a philosophical doctrine and perspective on society, utilitarianism was articulated by Jeremy Bentham and John Stuart Mill into an ethical system grounded on the principles of the laissez-faire economy theorized by Adam Smith (2008) [1776] at the dawn of the Industrial Revolution. Utilitarianism's basic tenet - the faith in an individual's calculative rationality employed by the latter to maximize his or her utility, conceived of in terms of personal wellbeing - has been taken over and incorporated within sociological thinking starting with the 1950s. In sociology, the utilitarian tradition had first 
appeared as the "social exchange theory" posited by George C. Homans (1958) and Peter M. Blau (1964) which sees social interaction as a transaction of goods and services between economic agents in pursuit of maximizing their profit. In the following decades, economically-minded social thinkers such as Gary S. Becker (1976) and James S. Coleman (1990) have renovated the utilitarian tradition under the guise of "rational choice theory."

From a utilitarian perspective, society is imagined in analogy to a social market, regulated by the "invisible hand" of the interplay between demand and supply, where essentially rational individuals struggle to maximize their personal profit through decision-making strategies based on a thorough costbenefit analysis. Within this economics-inspired theoretical imaginary, society is conceived of as being made up from a conglomerate of social markets, each of them subjected to the iron laws of market economy. For instance, credential inflation will occur on educational markets characterized by mass university education, as Randall Collins has shown in his book, The Credential Society (Collins 1979). Moreover, in a post-war gender disbalance scenario caused by large fatality numbers in the masculine population, a supply-induced scarcity on the marital market will occur (Boehnke and Gay 2020). Finally, in countries where state religions exist, the church monopoly exerted on the religious market produces declined rates of religious commitments and worship attendances (Iannaccone 1995). Utilitarianism's historical path from a philosophical current to an overarching theoretical framework within the social sciences can be metaphorically pictured "as a meandering stream across a low marshy plane."

Early on it was spring torrent, creating the river bed itself; then it narrowed and became a mere side channel to some better-established rivers; then again - in our own lifetimes - it has begun to flood, submerging the meadows and washing out the banks of the rivers that have been the separate social disciplines for the past century (Collins 1994: 122).

The latest overflowing of utilitarian thought has come under the guise of neoliberalism. An "oft-invoked but ill-defined concept" (Mudge 2008: 703), 
neoliberalism came to define a political economy which hails the market as a model of social organization and consequently enforces social and economic policies of privatization of the public sphere and deregulation of the market from normative constraints (Cahill and Konings 2017). Sociologists have traced "the arc of neoliberalism" as beginning in the 1970s and maturing a decade later with the administrations of Ronald Reagan in the United States and Margaret Thatcher in the United Kingdom. In their analyses, scholars have grasped neoliberalism by examining it from three interrelated vantage points: a) as an economic policy grounded on fiscalization, privatization, and market deregulation; b) as an expression of political power imposing the market-model of society; and c) as an ideational hegemony, with its core faith in the superiority of the unbound market - all of these united by the same underlying principle proclaiming "the necessity and desirability of transferring economic power and control from governments to private markets" (Centeno and Cohen 2012: 318). The rise of neoliberalism has entailed, besides accentuating uneven geographical developments in the world system (Harvey 2005; Wallerstein 1974), a growth of inequalities within each social system (Navarro 2007), the creation of a "precariat" social class (Molé 2010), and economic violence inflicted upon the poor (Wacquant 2009).

Economics, politics, and ideology - the three main nodes of the neoliberal paradigm - eventually intersected with a fourth dimension - space - in the commodification of landscape and, closer to my analytical interest here, the commodification of toponymy (Medway and Warnaby 2014). These elements all came together in cities, which are "the sites of both the most acute articulation of neoliberalism and of its most acute opposition" (Hackworth 2007: xii). Indeed, urban settlements provide privileged milieus in which to observe the neoliberalization process unfolding first through the roll-back of Keynesian arrangements (such as public housing and other welfare policies) followed by the roll-out of neoliberal measures reducing subsidized public services and promoting instead "workfare" policies (Peck 2001). The "neoliberal city" that emerged under these economic, political, and ideological auspices transformed both local politics (entrepreneurial city 
governance based on corporate-like management and public-private partnerships) and the physical and symbolic morphology of the city. In this regard, urban landscapes of neoliberal cities were transformed through realestate developments whose consequences consisted of increased gentrification. Indeed, as Jason Hackworth (2007) has put it, gentrification has been "the material and symbolic knife-edge of neoliberal urbanism" (p. 98).

On the cultural side, urban namescapes were also part of this neoliberal project. The neoliberal commodification of place-names has been at the core of a new wave of scholarship in social and cultural geography that shifted the research agenda of critical toponymies from the politics of place naming practices to accounting for the economic dimension of place-names (RoseRedwood 2011). Researchers who have taken up this challenge have documented the all-encompassing scope and the scalar politics of neoliberal toponymic commodification, as shown in Table 2 below. These changes range from renaming entire towns to changing the names of individual geographical units (such as streets) for revenue purposes. 
Table 2. Scalar politics of neoliberal toponymic commodification

\begin{tabular}{|c|c|c|}
\hline Scale & $\begin{array}{l}\text { Unit } \\
\text { re/naming }\end{array}$ & Examples \\
\hline Macro & Towns & $\begin{array}{l}\text { Blenheim, New Zealand (population c. 31,000) failed } \\
\text { proposal to change its name into Marlborough City } \\
\text { (2016) (Kearns and Lewis 2019). } \\
\text { Izumisano, Japan (population c. 100,000) auctioned the } \\
\text { city name rights for renting it to a private company } \\
\text { (2012) (Ryall 2012). }\end{array}$ \\
\hline \multirow[t]{2}{*}{ Meso } & Neighborhoods & $\begin{array}{l}\text { New York City's residential complexes branded by } \\
\text { their developers as ProCro, BoCoCa, Rambo, } \\
\text { Clinton, Piano District (Madden 2018). } \\
\text { NYC's Navy Yard District (stereotyped in the public } \\
\text { imagination as an exotic slum and referred to as } \\
\text { Hell's Half Acre and The Jungle) was renamed as } \\
\text { Vinegar Hill and redeveloped for privileged class } \\
\text { urbanites (Madden 2018). }\end{array}$ \\
\hline & $\begin{array}{l}\text { Transport } \\
\text { infrastructure }\end{array}$ & $\begin{array}{l}\text { Tampa, Florida renamed its entire heritage transit line } \\
\text { after the local energy-related holding company } \\
\text { (Light and Young 2014) }\end{array}$ \\
\hline Micro & Streets & $\begin{array}{l}\text { Examples from Hungary: Auchan Street in Törökbálint, } \\
\text { Mercedes Street in Kecskemét, Nokia Street in } \\
\text { Komárom, Samsung Square in Jászfényszaru (Light } \\
\text { and Young 2014). }\end{array}$ \\
\hline \multirow[t]{3}{*}{ Nano } & Institutions & $\begin{array}{l}\text { Zuckerberg San Francisco General Hospital and } \\
\text { Trauma Center (SFGH) named after Mark } \\
\text { Zuckerberg, Facebook's co-founder and chief } \\
\text { executive officer (CEO) (McElroy 2019) }\end{array}$ \\
\hline & Sport stadia & $\begin{array}{l}\text { In the English Premier League (EPL), football clubs } \\
\text { such as Arsenal FC and Manchester City FC have } \\
\text { sold the name rights of their stadia to sponsors like } \\
\text { Emirates and Etihad. } \\
\text { In Germany's Bundesliga, FC Bayern Munich play their } \\
\text { home games in the Allianz Arena, while the home } \\
\text { ground of Borussia Dortmund is now officially } \\
\text { named Signal Iduna Park after a German financial } \\
\text { services company (Vuolteenaho, Wolny, and Puzey } \\
\text { 2019) }\end{array}$ \\
\hline & $\begin{array}{l}\text { Public } \\
\text { transport } \\
\text { stations }\end{array}$ & $\begin{array}{l}\text { Individual bus, train, and metro stations in New York } \\
\text { City, Las Vegas, Winnipeg, Dubai, Budapest (Rose- } \\
\text { Redwood, Sotoudehnia, and Tretter 2019) }\end{array}$ \\
\hline
\end{tabular}

Source: author's elaboration 
At the broadest level, entire towns have been subjected to neoliberal toponymic commodification. Although there are historical antecedents - for example, in 1959 the Japanese town of Koromo changed its name into Toyota City (Anttiroiko 2014) - the phenomenon has gained increased traction during the last decade. In a bid to lure Google into unfolding its ultra-fast broadband experiment in Topeka, Kansas, the mayor has temporarily proclaimed the town as "Google, Kansas - the capital city of fiber optics" for the month of March 2010 (Bosker 2010). The company has responded by changing its name to Topeka in the search engine portal on April Fools' prank (Smith 2010). In 2005, the residents of Clark, Texas have agreed to rename their town as Dish, after the television provider Dish Network, in exchange for receiving free TV service (Fernandez 2013). Across the Pacific Ocean, in 2012, the nearlybankrupt Japanese town of Izumisano, Osaka organized auctions to rent out its name to private companies willing to pay the price (Ryall 2012). However, such extreme neoliberal measures of branding places rarely go uncontested. When the representatives of local businesses championed the idea of renaming Blenheim, New Zealand into Marlborough City to promote the region's wine industry, made famous by the brand "Marlborough Sauvignon Blanc," residents opposed the proposal which was ultimately abandoned (Kearns and Lewis 2019). This made evident the clash of visions that pitted the local business elite's view of Blenheim as boring and unmarketable to the denizens' emotional attachment to the place name which they consider a pillar of their identity. In making visible the contentious politics of branding place-names, this example also points out the limits of the neoliberal imperatives of toponymic commodification, which can sometimes be thwarted through civic contestation.

At a lower level, neighborhoods, city districts, and residential complexes were renamed in neoliberal attempts to rise the real-estate value of these urban areas through the toponymic means of "luxury inscription" (Rofe 2003: 2522). In this regard, David J. Madden (2018) has charted what he called the "toponymy of inequality" which produces gentrification and symbolic displacement as an outcome of renaming the neighborhoods of New York 
City as part of public-private neoliberal partnerships of urban development. In New York and elsewhere in the neoliberal world, "stigmatized place names are being erased as part of the destruction of unprofitable cityscapes" only to be reinscribed with names that render the redeveloped areas attractive on the real estate market (Madden 2018; for similar developments in Manchester's neighborhoods, see Light and Young 2014: 442).

At the nano level on this scale of toponymic commodification, individual geographical units such as metro stations, public institutions, and sports stadia have been named after sponsors who have acquired the naming rights sold by public authorities. Mass transport infrastructures from cities around the world have been among the first to experience this neoliberal privatization. Whereas the names of train and metro stations from New York and Las Vegas to Budapest and Dubai have been sold to private buyers for big money (for example, Barclays Bank paid $\$ 4$ million for a station in the New York City's metro system), local authorities from Tampa, Florida have sold the naming rights for an entire public transport line to a utilities company, now called the TECO Line Streetcar System (Light and Young 2014: 441; Rose-Redwood, Sotoudehnia, and Tretter 2019).

Similar privatizations involved the names of hospitals (e.g., the rebranding of the Zuckerberg San Francisco General Hospital and Trauma Center after Facebook's founder following his multi-million dollar donation, see McElroy 2019) and especially entertainment venues and sports stadia. A cross-national quantitative study based on data collected from several European countries found that a third of the football grounds venues from the top two national leagues from England/Wales, Finland, Germany, Italy, Norway, and Scotland have been named after a sponsor $(33.2 \%$, that is 63 out of 193) (Vuolteenaho, Wolny, and Puzey 2019). The authors have also charted different national cultures of neoliberal toponymic commodification, with Germany having the highest proportion of football stadia bearing sponsors' names $(74.3 \%)$, whereas in Italy the practice of selling stadia's naming rights is the least common (8.1\%). In England and Wales, where the trend started, 
$33.3 \%$ of the stadia are named after sponsors, including Arsenal FC's Emirates Stadium and Manchester City FC's Etihad Stadium.

Bolton Wanderers FC's stadium's naming odyssey provides a glimpse into the fragility of neoliberal toponymy. Opened in 1997 as Reebok Stadium (after the English footwear company), it was renamed in 2004 as Macron Stadium (after the Italian sportswear company). In 2018, when the naming rights expired, it was again renamed as the University of Bolton Stadium. What this sequence of fast pace name changes driven by renegotiated naming rights contracts fully reveals is that in neoliberal times, economic capital has supplanted political power as the main structuring factor of urban namescapes. Until recently, it was the political regime changes that punctuated the remaking of place-names and street nomenclatures (Light, Suditu, and Nicolae 2002; Light 2004; Rusu 2020b). These political events were responsible for the toponymic incoherence and palimpsestic nature of urban street names recognized by various scholars. In Paris, Priscilla P. Ferguson (1986) has pointed out that "on streets as in cemeteries synchronicity effaces the enmities of life, dissociates the affinities, and jumbles historical ties of every sort. Kings and revolutionaries, political enemies, and literary rivals exist side by side" (p. 392). This "crazy-quilt, almost surreal poetry imprinted on the city by these arbitrary links of people and places" created by the "veritable mania of de- and re-baptizing" inaugurated by the French Revolution (Ferguson 1988: 390, 393) derives its palimpsestic character from the accumulation of residual toponymies inherited from the earlier political formations that left their mark on parts of the city fabric. In the neoliberal city, given the time-limited nature of naming rights, change and instability become a built-in structural feature of the political economy of urban space. Neoliberalism produces a "restless" urban landscape, as Paul L. Knox (1991) has shown by examining the changes in the built environment of Metropolitan Washington, D.C. It also leads to the creation of a structurallydetermined unstable namescape, as the time-bounded renting of naming rights for public spaces is intermittently renegotiated. 
Urban nomenclatures have also become "emerging spaces of neoliberalism" (Candan and Kolluoğlu 2008), as individual streets started to be targeted for renaming to advance corporate interests. This trend is nowhere more visible than in Hungary, where several municipalities, ranging from the capital city Budapest to the townlet of Jászfényszaru (population c. 5,000), have named streets after businesses (Auchan Street in Törökbálint, Mercedes Street in Kecskemét, Nokia Street in Komárom, Samsung Square in Jászfényszaru) (Light and Young 2014: 442). Instead of celebrating the occupational structure reflected in medieval craft guilds and industrial professions (e.g., Drapers Street or Welders Lane), the urban streetscape becomes a canvas for inscribing firm names and a public extension of the corporate visual identity.

It is not only the names themselves that are commodified under neoliberal imperatives. These have also permeated into the material infrastructure underpinning the physical signage of street names (Light and Young 2014: 444). Entrepreneurial municipalities have gone as far as deploying urban road signs that embed by design places for street advertising, as shown in the image below taken in Oradea, Romania. This shows how the road signs indicating Calea Republicii (Republic Avenue) and Str. Mihai Eminescu (Romania's "national poet," 1850-1889) - representing an ideological value and a cultural icon of Romania's historical memory and political identity - serve as material support for advertisements for a local pizza shop. Needless to say, such commercial additions undermine and subvert the political ethos communicated through the commemorative street names. Around the corner, on the street named after the $19^{\text {th }}$ century painter Nicolae Grigorescu (1838-1907), the sign includes an ad to painting frames, which shows that an organic symbiosis between the cultural legacy and neoliberal interests is also possible. 
Figure 1. Neoliberal commodification of road signs in Oradea, Romania

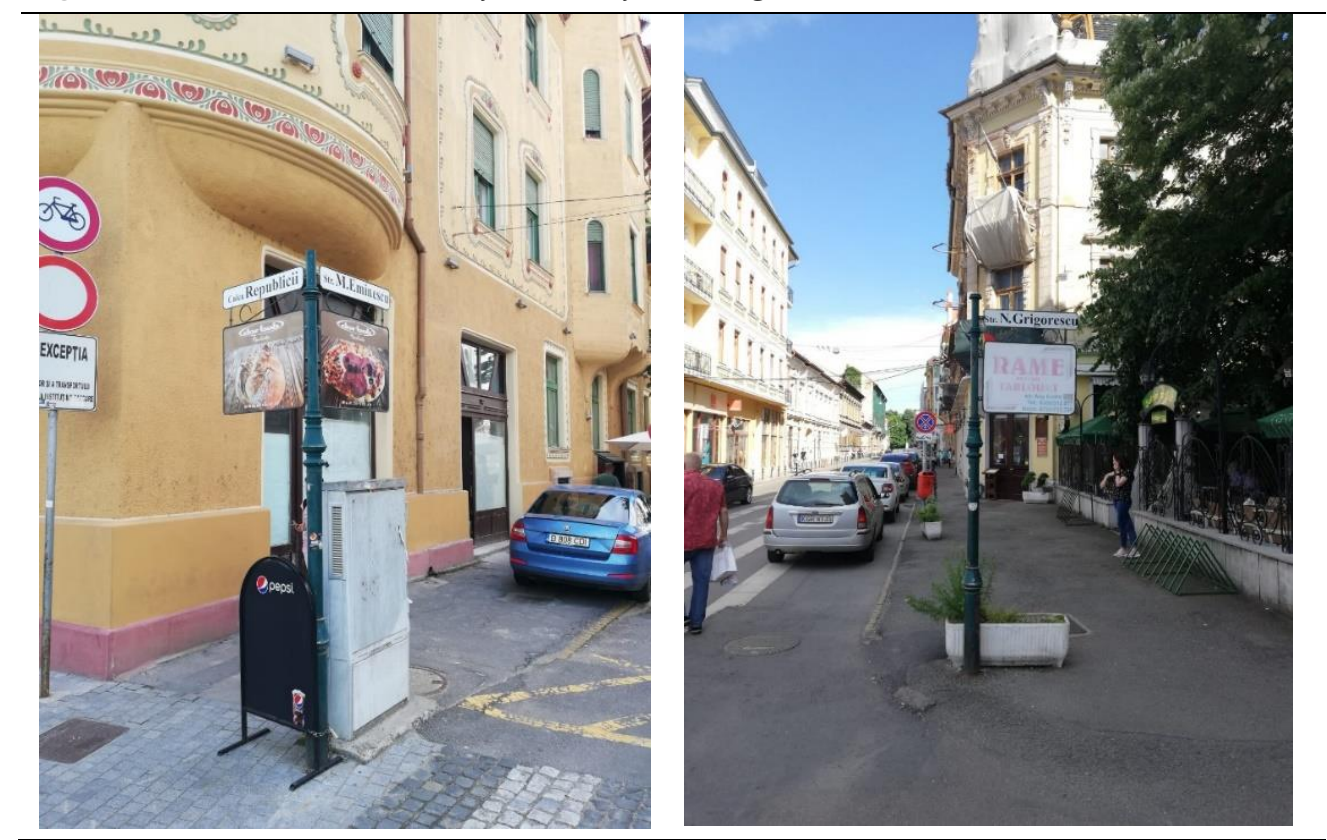

Source: Author's personal archive (the pictures were taken in 2019).

Such symbiotic arrangements can be made theoretical sense of through the notion of "symbolic accretion" coined by Kenneth E. Foote (1997), understood as a process of reinforcing the meaning of a memorial site by the construction of additional monuments onto the very same place (pp. 231-232). In his analysis of the contentious politics of commemoration as expressed in erecting monuments, Owen J. Dwyer (2004) has further refined the term by distinguishing between the "allied" and "antithetical" modes of symbolic accretion. While the former "enhances and confirms the dominant discourses associated with a memorial," the latter is "counter-intentional and seeks to contradict or otherwise adjust the conventional message of the monument" (p. 421). Drawing on these conceptual resources, I argue that the case of Oradea pictured above epitomizes a form of hybrid symbolic accretion in which the two co-present messages are neither mutually reinforcing nor antithetical to each other but can coexist together. It is not simply the case that neoliberalism supplants nationalism as the new hegemonic ideology reigning 
over the urban landscape. Instead, as the example from Oradea's Str. Nicolae Grigorescu shows, commercial interests can be grafted upon the existing layer of political symbols and cultural icons. Indeed, "the brandscape coexists with other toponymic registers [...] but increasingly, the city appears as a constellation of corporate trademarks" that are toponymically inscribed onto the streetscape and other public places or granted upon the pre-existing namescape (Madden 2019: 888).

In making sense of these neoliberal privatizations of naming rights and commodification of public space, scholars have employed Pierre Bourdieu's (1986) theory of capitals. Rejecting the over-simplistic Marxist notion that economic capital rests at the core of inequalities characterizing the social world, the French sociologist posited that other forms of capital - social, cultural (in its three-fold expression as embodied in knowledge and habitus, objectified in material artifacts, and institutionalized in academic credentials and professional qualifications), and symbolic, among other - are just as important. In Bourdieu's (1984) understanding, developed at length in his book Distinction: A Social Critique of the Judgement of Taste, symbolic capital consists in the possession of immaterial assets which grant their holder social prestige, honor, legitimacy, and recognition. A crucial aspect of Bourdieu's theory lies in the convertibility of capitals, where a type of capital can be strategically managed so as to acquire another type (e.g., symbolic into economic and vice versa). This dialectical inter-conversion between symbolic and economic forms of capital is clearly at work in the toponymic commodification of urban landscape enacted through public-private partnerships (entrepreneurial municipalities in association with real-estate developers and corporate businesses) within the neoliberal city.

Critical scholars of these developments have drawn attention to the "major motif of the neoliberal city: dispossession, in the form of city dwellers stripped of common identifiers, spaces, property, and institutions" (Madden 2019: 889). To be sure, the symbolic appropriation of public space and urban namescape by corporate interests constitutes a "political technology of neoliberal governance" (Rose-Redwood, Vuolteenaho, Young, and Light 
2019: 2) that is amenable to a sociological analysis from a Foucauldian perspective. Drawing on another classical theme in historical sociology, these developments can also be accounted for in terms of Jürgen Habermas's (1989) theory of the colonization of the public sphere, whereby the spatial infrastructure of social life together with its nominal identifiers are being subjected to an aggressive process of neoliberal "capturing" by allencompassing commercial interests (Kearns and Lewis 2019).

\section{Conclusions}

Street names are important features of urban landscapes that have been conspicuously missing from sociologists' research agenda. Their importance in the construction of place through inscribing onto the landscape collective memories and political statements that tell specific narratives of historical becoming and social belonging has not gone unnoticed in other parts of social sciences, which have done much to unravel the intricate entanglements of power, language, and identity embedded in the spatial practices of street (re)naming.

As this literature review article has thoroughly documented, the scholarly study of place- and street naming practices developed in the disciplinary field of human geography, with little - if any - significant contributions from sociologists. However, although sociologists have refrain from engaging in theoretical debates and empirical research on street names, concepts and theories developed by sociologists have been employed by critical scholars of toponymies in their analyses (e.g., Simmel's (2009) fleeting thoughts on numerical streetscapes, Bourdieu's (1986) theory of capitals). What I have attempted to achieve in this overview of the literature was to realign the work done on toponymies along the coordinates of sociological theories. My analysis of the existing scholarship in critical place-name studies in terms of functionalist, conflictualist, constructionist, and utilitarian paradigmatic outlooks developed in sociological theory has shown that street nomenclatures can constitute a rewarding object of sociological analysis. This 
promise is grounded on the consideration that urban toponymy encapsulates broader issues of power, identity, memory, and language - all of these intersecting in specific geospatial settings - that can be rendered visible through sociological analysis.

From identifying the functions and dysfunctions of street names along functionalist lines of inquiry to unpacking the essential tensions underpinning the contested politics of toponymic practices from a conflict perspective, sociologists can contribute to further enriching this already vibrant field of study. Moreover, from decoding the structures of meaning institutionalized in the urban streetscape through constructionist and symbolic-interactionist analyses to examining the toponymic commodification of space through the utilitarian lens provided by the rational choice theory, a sociology of street names promises to contribute with sensible answers to Shakespeare's still intriguing question, "What's in a name?"

\section{Acknowledgements}

This work was supported by a grant of the Romanian Ministry of Education and Research, CNCS-UEFISCDI, project number PN-III-P1-1.1-TE-2019-0238, within PNCDI III.

\section{References:}

Anttiroiko, Ari-Veikko. 2014. The Political Economy of City Branding. Abington and New York, NY: Routledge.

Azaryahu, Maoz. 1990. 'Renaming the Past: Changes in "City Text" in Germany and Austria, 1945-1947'. History and Memory, 2(2): 32-53.

Azaryahu, Maoz. 1996. 'The Power of Commemorative Street Names'. Environment and Planning D: Society and Space, 14: 311-330.

Azaryahu, Maoz. 2012. 'Renaming the Past in Post-Nazi Germany: Insights into the Politics of Street Naming in Mannheim and Potsdam'. Cultural Geographies, 19(3): 385-400.

Barthes, Roland. 1997. 'Semiology and the Urban'. In Neil Leach (ed.). Rethinking Architecture: A Reader in Cultural Theory. London and New York, NY: Routledge, 158-164. 
Becker, Gary S. 1976. The Economic Approach to Human Behavior. Chicago, IL: University of Chicago Press.

Berg, Lawrence D. and Jani Vuolteenaho. (Eds.). 1999. Critical Toponymies: The Contested Politics of Place Naming. Farnham: Ashgate.

Berger, Peter L. and Thomas Luckmann. 1966. The Social Construction of Reality: A Treatise in the Sociology of Knowledge. New York, NY: Anchor Books.

Bigon, Liora. 2009. 'Urban Planning, Colonial Doctrines and Street Naming in French Dakar and British Lagos, c. 1850-1930'. Urban History, 36: 426448.

Blau, Peter M. 1964. Exchange and Power in Social Life. New York, NY: Wiley.

Blumer, Herbert. 1969. Symbolic Interactionism: Perspective and Method. Berkeley, CA: University of California Press.

Boehnke, Jörn and Victor Gay. 2020. 'The Missing Men: World War I and Female Labor Force Participation'. The Journal of Human Resources, DOI: $10.3368 /$ jhr.57.4.0419-10151R1.

Bosker, Bianca. 2010. 'Google, Kansas: Topeka Mayor Renames City In Bid To Win Google Broadband'. HuffPost, 5 February 2010. Available online at https://www.huffpost.com/entry/google-kansas-topekamayo_n_482303.

Bourdieu, Pierre. 1986. 'The Forms of Capital'. In John Richardson (Ed.). Handbook of Theory and Research for the Sociology of Education. New York, NY: Greenwood, 241-258.

Bourdieu, Pierre. 1984. Distinction: A Social Critique of the Judgement of Taste. Cambridge, MA: Harvard University Press.

Burr, Vivien. 1995. Social Constructionism. London and New York, NY: Routledge.

Cahill, Damien and Martijn Konings. 2017. Neoliberalism. Cambridge: Polity.

Candan, Ayfer Bartu and Biraly Kolluoğlu. 2008. 'Emerging Spaces of Neoliberalism: A Gated Town and a Public Housing Project in İstanbul'. New Perspectives on Turkey, 39: 5-46.

Centeno, Miguel A. and Joseph N. Cohen. 2012. 'The Arc of Neoliberalism'. Annual Review of Sociology, 38: 317-340.

Chloupek, Brett R. 2019. 'Public Memory and Political Street Names in Košice: Slovakia's Multiethnic Second City'. Journal of Historical Geography, 64: 25-35.

Cohen, Saul B. and Nurit Kliot. 1992. 'Place-Names in Israel's Ideological Struggle over the Administered Territories'. Annals of the Association of American Geographers, 82(4): 653-680.

Coleman, James S. 1990. Foundations of Social Theory. Cambridge, MA: Harvard University Press. 
Collins, Randal. 1979. The Credential Cociety: An Historical Sociology of Education and Stratification. New York, NY: Academic Press.

Collins, Randall. 1994. Four Sociological Traditions. Revised and Enlarged Edition. Oxford: Oxford University Press.

Crețan, Remus and Phillip W. Matthews. 2015. 'Popular Responses to CityText Changes: Street Naming and the Politics of Practicality in a PostSocialist Martyr City'. Area, 48(1): 92-102.

Duncan, James S. .1990. The City as Text: The Politics of Landscape Interpretation in the Kandyan Kingdom. Cambridge: Cambridge University Press.

Dwyer, Owen J. 2004. 'Symbolic Accretion and Commemoration'. Social E Cultural Geography, 5(3):419-435.

Dwyer, Owen J. and Derek Alderman. 2008. 'Memorial Landscapes: Analytic Questions and Metaphors'. GeoJournal, 73: 165-178.

Ferguson, Priscilla P. 1988. Reading City Streets. The French Review, 61(3): 386397.

Fernandez, Manny. 2013. 'Marketing Deal Gives a Small Town an Identity Crisis'. The New York Times, 21 March 2013. Available online at https://www.nytimes.com/2013/03/22/us/texas-town-called-dishhas-an-identity-problem.html.

Foote, Kenneth E. 1997. Shadowed Ground: America's Landscapes of Violence and Tragedy. Austin, TX: University of Texas Press.

Foucault, Michel. 1972. The Archeology of Knowledge and the Discourse on Language. New York, NY: Pantheon Books.

Foucault, Michel. 1980. Power/Knowledge: Selected Interviews and Other Writings, 1972-1977. New York, NY: Pantheon Books.

Gill, Graeme. 2005. 'Changing Symbols: The Renovation of Moscow Place'. Russian Review, 64(3): 480-403.

Giraut, Frédéric and Myriam Houssay-Holzschuch. 2016. 'Place Naming as Dispositif: Toward a Theoretical Framework'. Geopolitics, 21(1): 1-21.

Habermas, Jürgen. 1989. The Structural Transformation of the Public Sphere: An Inquiry Into a Category of Bourgeois Society. Cambridge, MA: MIT Press.

Hackworth, Jason. 2007. The Neoliberal City. Ithaca, NY and London: Cornell University Press.

Harvey, David. 2005. A Brief History of Neoliberalism. Oxford: Oxford University Press.

Hobbes, Thomas. 2008. Leviathan. Oxford: Oxford University Press.

Iannaccone, Laurence R. 1995. 'Voodoo Economics? Reviewing the Rational Choice Approach to Religion'. Journal for the Scientific Study of Religion, 34(1): 76-88. 
Homans, George C. 1958. 'Social Behavior as Exchange'. American Journal of Sociology, 63(6): 597-606.

Kearns, Robin A. and Nicolas Lewis. 2019. 'City Renaming as Brand Promotion: Exploring Neoliberal Projects and Community Resistance in New Zealand'. Urban Geography, 40(6): 870-887.

Knox, Paul L. 1991. 'The Restless Urban Landscape: Economic and Sociocultural Change and the Transformation of Metropolitan Washington, DC'. Annals of the Association of American Geographers, 81(2): 181-209.

Landry, Rodrigue and Richard Y. Bourhis. 1997. 'Linguistic Landscape and Ethnolinguistic Vitality: An Empirical Study'. Journal of Language and Social Psychology, 16(1): 23-49.

Light, Duncan and Craig Young. 2014. 'Toponymy as Commodity: Exploring the Economic Dimensions of Urban Place Names'. International Journal of Urban and Regional Research, 39(3): 435-450.

Light, Duncan, Suditu, Bogdan, and Ion Nicolae. 2002. 'Toponymy and the Communist City: Street Names in Bucharest, 1948-1965'. GeoJournal, 56: 135-144.

Light, Duncan. 2004. 'Street Names in Bucharest, 1990-1997: Exploring the Modern Historical Geographies of Post-Socialist Change'. Journal of Historical Geography, 30: 154-172.

Madden, David J. 2018. 'Pushed Off the Map: Toponymy and the Politics of Place in New York City'. Urban Studies, 55(8): 1599-1614.

Madden, David J. 2019. 'The Names of Urban Dispossession: A Concluding Commentary'. Urban Geography, 40(6): 888-892.

McElroy, Erin. 2019. 'Data, Dispossession, and Facebook: Techno-Imperialism and Toponymy in Gentrifying San Francisco'. Urban Geography, 40(6): 826-845.

Mead, George Herbert. 1934. Mind, Self, and Society: From the Standpoint of a Social Behaviorist. Chicago, IL: Chicago University Press.

Medway, Dominic and Gary Warnaby. 2014. 'What's in a Name? Place Branding and Toponymic Commodification'. Environment and Planning A: Economy and Space, 46: 153-167.

Molé, Noelle J. 2010. 'Precarious Subjects: Anticipating Neoliberalism in Northern Italy's Workplace'. American Anthropologist, 112(1): 38-53.

Mudge, Stephanie Lee. 2008. 'What is Neo-Liberalism'. Socio-Economic Review, 6(4): 703-731.

Navarro, Vicente. 2007. 'Neoliberalism as a Class Ideology; Or, the Political Causes of the Growth of Inequalities'. International Journal of Health Services, 37(1): 47-62. 
Palonen, Emilia. 2008. 'The City-Text in Post-Communist Budapest: Street Names, Memorials, and the Politics of Commemoration'. GeoJournal, 73: 219-230.

Palonen, Emilia. 2015. 'The Politics of Street Names: Local, National, Transnational Budapest'. In Marnix Beyen and Brecht Deseure (Eds.). Local Memories in a Nationalizing and Globalizing World. Basingstoke: Palgrave Macmillan, 51-71.

Peck, Jamie. 2001. 'Workfare versus Cities'. Urban Geography, 22(5): 493-498. Polanyi, Michael. 1958. Personal Knowledge: Towards a Post-Critical Philosophy. London and New York, NY: Routledge \& Kegan Paul.

Rofe, Matthew W. 2003. "II Want to be Global": Theorising the Gentrifying Class as an Emergent Elite Global Community'. Urban Studies, 40(12): 2511-2526.

Rose-Redwood, Reuben, Alderman, Derek and Maoz Azaryahu. 2010. 'Geographies of Toponymic Inscription: New Directions in Critical Place-Name Studies'. Progress in Human Geography, 34(4): 453-470.

Rose-Redwood, Reuben, Alderman, Derek and Maoz Azaryahu. (Eds.) 2018. The Political Life of Urban Streetscapes: Naming, Politics, and Place. London and New York, NY: Routledge.

Rose-Redwood, Reuben, Sotoudehnia, Maral, and Eliot Tretter. 2019. “"Turn Your Brand into a Destination": Toponymic Commodification and the Branding of Place in Dubai and Winnipeg'. Urban Geography, 40(6): 846-869.

Rose-Redwood, Reuben, Vuolteenaho, Jani, Young, Craig and Duncan Light. 2019. 'Naming Rights, Place Branding, and the Tumultuous Cultural Landscapes of Neoliberal Urbanism'. Urban Geography, 40(6): 747-761.

Rose-Redwood, Reuben. 2011. 'Rethinking the Agenda of Political Toponymy'. ACME: An International Journal for Critical Geographies, 10(1): 34-41.

Rusu, Mihai Stelian. 2019a. 'Mapping the Political Toponymy of Educational Namescapes: A Quantitative Analysis of Romanian School Names'. Political Geography, 72: 87-98.

Rusu, Mihai Stelian. 2019b. 'Shifting Urban Namescapes: Street Name Politics and Toponymic Change in a Romanian(ised) City.' Journal of Historical Geography, 65: 48-58.

Rusu, Mihai Stelian. 2020a. 'Street Names through Sociological Lenses. Part I: Functionalism and Conflict Theory'. Social Change Review, 18(1-2), doi: 10.2478/scr-2020-0001. 
Rusu, Mihai Stelian. 2020b. ‘Political Patterning of Urban Namescapes and Post-socialist Toponymic Change: A Quantitative Analysis of Three Romanian Cities'. Cities, 103: 102773.

Ryall, Julian. 2012. 'Mitsubishiville? Bankrupt Japanese Town to Rent Naming Rights to Companies.' The Telegraph, 23 March 2012. Available online at

https://www.telegraph.co.uk/news/newstopics/howaboutthat/916 2224/Mitsubishiville-bankrupt-Japanese-town-to-rent-namingrights-to-companies.html.

Šakaja, Laura and Jelena Stanić. 2018. 'The Spatial Codification of Values in Zagreb's City-Text'. In Reuben Rose-Redwood, Derek Alderman, and Maoz Azaryahu (Eds.). The Political Life of Urban Streetscapes: Naming, Politics, and Place, London and New York, NY: Routledge, 150-167.

Schütz, Alfred. 1967. The Phenomenology of the Social World. Evanston, IL: Northwestern University Press.

Siani-Davies, Peter. 2007. The Romanian Revolution of December 1989. Ithaca, NY and London: Cornell University Press.

Simmel, Georg. 2009. Sociology: Inquiries into the Construction of Social Forms. Volume 2. Leiden and Boston, MA: Brill.

Smith, Aaron. 2010. 'Google's April Fools' Prank: We're Now Topeka'. CCN Money, 1 April 2010. Available online at https://money.cnn.com/2010/04/01/technology/google_april_fool s/.

Smith, Adam. 2008. An Inquiry into the Nature and Causes of the Wealth of Nations. Oxford: Oxford University Press.

Strauss, Anselm S. 1978. Negotiations: Varieties, Processes, Contexts, and Social Order. San Francisco, CA: Jossey-Bass.

Vuolteenaho, Jani, Wolny, Matthias, and Guy Puzey. 2019. “"This Venue is Bought to You By...": The Diffusion of Sports and Entertainment Facility Name Sponsorship in Urban Europe'. Urban Geography, 40(6): 762-783.

Wacquant, Loïc. 2009. Punishing the Poor: The Neoliberal Government of Social Insecurity. Durham, NC: Duke University Press.

Wallerstein, Immanuel. 1974. The Modern World-System. New York, NY: Academic Press.

Yeoh, Brenda S. A. 1992. 'Street Names in Colonial Singapore'. Geographical Review, 82(3): 313-322.

Yeoh, Brenda S. A. 1996. 'Street-Naming and Nation-Building: Toponymic Inscriptions of Nationhood in Singapore'. Area, 28(3): 298-307. 